Article

\title{
Revitalizing the Successful Past in the North: Narratives of Change in the Peripheral Post-Industrial City of Kajaani, Finland
}

\author{
Simo Häyrynen * and Jussi Semi \\ Department of Geographical and Historical Studies, University of Eastern Finland, 70210 Kuopio, Finland; \\ jussi.semi@uef.fi \\ * Correspondence: simo.hayrynen@uef.fi
}

Received: 14 October 2019; Accepted: 3 December 2019; Published: 8 December 2019

\begin{abstract}
Finding a new destination for declining industrial communities is a common European trend, wherein local, national and EU interests are intertwined and sometimes contested. New meaning is sought, among other things, in economics, political activity, and images of the past. This article analyzes local development narratives in the case of the "northern periphery". This paper highlights how the shrinking town of Kajaani, Finland, reacts to the state's changing role in regional industrial strategies by comparing different local interpretations of future expectations. The research material comprises interviews, city strategies, and editorials from a local newspaper. This paper suggests that the previously dominant narrative of decentralization still holds sway in the minds of the local advocates. However, it is flavored by the narrative of the knowledge-based economy forming three interrelated local narratives: the narrative of the small town; the narrative of closure; and the narrative of traction. The analysis shows that a northern model city of former industrial policy is seeking to reform and develop its original strengths. However, strong links to previous doctrines of state regional policy still frame the potential of local interpretations and make them specifically Nordic development narratives.
\end{abstract}

Keywords: development narratives; northern periphery; post-industrial development; decentralization; revitalization strategy; knowledge-based economy

\section{Introduction}

\subsection{A Place That Would like to Matter Again}

In recent decades, there has been rapid change in traditional industries, industrial areas and industrial towns all over Europe [1]. Declining post-industrial communities seek to cope with reductions in the working-age population and declines in public finance. Many such communities have recently lost not only their status in national and worldwide economic structures but also significant elements of their collective identities [2]. However, some suggest that change in industries may also provide opportunities to create something new. Resilient communities would have dynamic capabilities to react to negative events and changes, to emphasize their distinctive contextual factors and promote new development trajectories [3]. How this works in the case of the peripheral city of Kajaani in northern Finland is at stake in this article.

A feature of late capitalism is that city regions intertwine competitiveness, the knowledge-based economy, and the rise of a creative class and cultural industry [4-7]. Academic discourse has generally dealt with metropolises, while ignoring smaller cities and towns. Cities and metropolises enjoy many advantages smaller towns lack, such as the concentration of experts and other actors that make cities richer, smarter, and happier [2,8]. It is this discourse that smaller and declining towns have to cope with 
today. This paper focuses on a 'place that doesn't matter', referring to Andrés Rodriguez-Pose's [9] article. Rodriguez-Pose maintains that such places are sometimes falsely labeled as places having no future and are largely ignored in academic and policy debates.

How do communities try to make them matter again? What kind of strategic moves are to be recognized in a peripheral industrial community facing transitional changes in its post-productive phases? It is obvious that post-industrial experience varies according to the social context and industrial tradition of the community. Industrialized cities in the northern peripheries have also lost their former significance [10]. However, their perspective differs from the earlier industrialized and more densely populated areas of Europe. Firstly, the symbolic meaning of the relatively isolated industrial islands for both the whole state and especially for surrounding developing areas is emphasized. In Finland, but also in the neighboring welfare states, Norway and Sweden, isolated industrial communities have often formed virtual enclaves in local regions. They have been a kind of localized civilizing process, securing not only the needs of industry but the symbolic value and remote borders of the sparsely populated areas, making both the nations and operating communities more cohesive and committed (2). Therefore, as far as the northern sparsely populated areas are at stake, the expression "knowledge-based industries" as a contrast to resource-based primary industries has proved misleading, for the latter are similarly important distributors of knowledge and innovations in their surroundings. Industrial towns are "outposts" of not only technological development but they also represent civilized society in a much more profound sense (2pp. 7-8). Secondly, the 'civilizing project' gets extra flavor from the long history of centrally organized regional policy in Finland. Areas that are in decline are still heavily supported by the state as a heritage of the welfare state, even if the former appreciation of basic industry has declined.

This change in symbolic meaning and culturally motivated national industrial strategy has clearly been unresearched in the study of European post-industrialization. Little attention has been paid to how the Fordist ideals of the past-functional division of labor, top-down hierarchy-are associated with the modern ideals of high technology and the diverse creative class in the case of highly decentralized national industrial strategies. Usually coping with great changes happens by creating both compatible and credible enough paths from the past to the future (2). Therefore, to explain what difference changes in symbolic meaning cause to the coping strategies of post-industrial towns, we apply narrative analysis. The point is that discursive connections of facts and desires take the form of a narrative. Narrative analysis is a tool for collecting people's experiences and relating them to broader social relations and developments. Especially as the strategical environment drastically changes, the importance of development narratives increases [11]. They help to adapt to change and to connect previously alien elements to each other. Therefore, this article seeks to identify such narratives and their connections through interviewing local developers and analyzing local documentary material. In tight industrial communities the dominance of the dominant narrative can be based on a relatively coherent perception of common good and duties, meaning that competing or alternative storylines may be rare or absent. This article discusses the dominant narrative the advocates of the case study town try to both sustain and reformulate. It analyzes the variety of local adaptations in their relation to the dominant narrative. Furthermore, since the post-industrial narratives do not evolve in a social vacuum, the study is connected with the transformation of Finnish statehood and its effects on the regional industrial policies [12].

\subsection{The Case Study Town: Kajaani}

The study focuses on the town of Kajaani. Kajaani is an ideal example of studying the order of development narratives, because it historically indicates changes in the industrialization strategies for the outermost regions of Finland. It is a Finnish inland town 500 kilometers north from Helsinki (see Figure 1). The town's proximity to transport routes has affected the growth of the town's forest industry. At the beginning of the twentieth century, the railroad, teacher training college, and timber company (previously Kajaani Oy and, after corporate acquisition, UPM) spurred the town's growth. 
The paper industry was the most obvious industrial employer for a long time. However, the big paper mill closed in 2008. A large employment replacement program and the reuse of factory facilities met its targets. New jobs have been created in both traditional and new sectors, with the the latter including a call center, IT companies, and a pilot plant for bioethanol. However, the town and region are suffering from depopulation and an inability to attract newcomers-largely a product of its distant location, high unemployment, thin economic base, and limited education options. Alongside the closure of the paper mill, a teacher training unit that was part of the University of Oulu closed in 2012. The town thus has many of the features of the 'place that doesn't matter' in Rodriguez-Pose's [9] article.

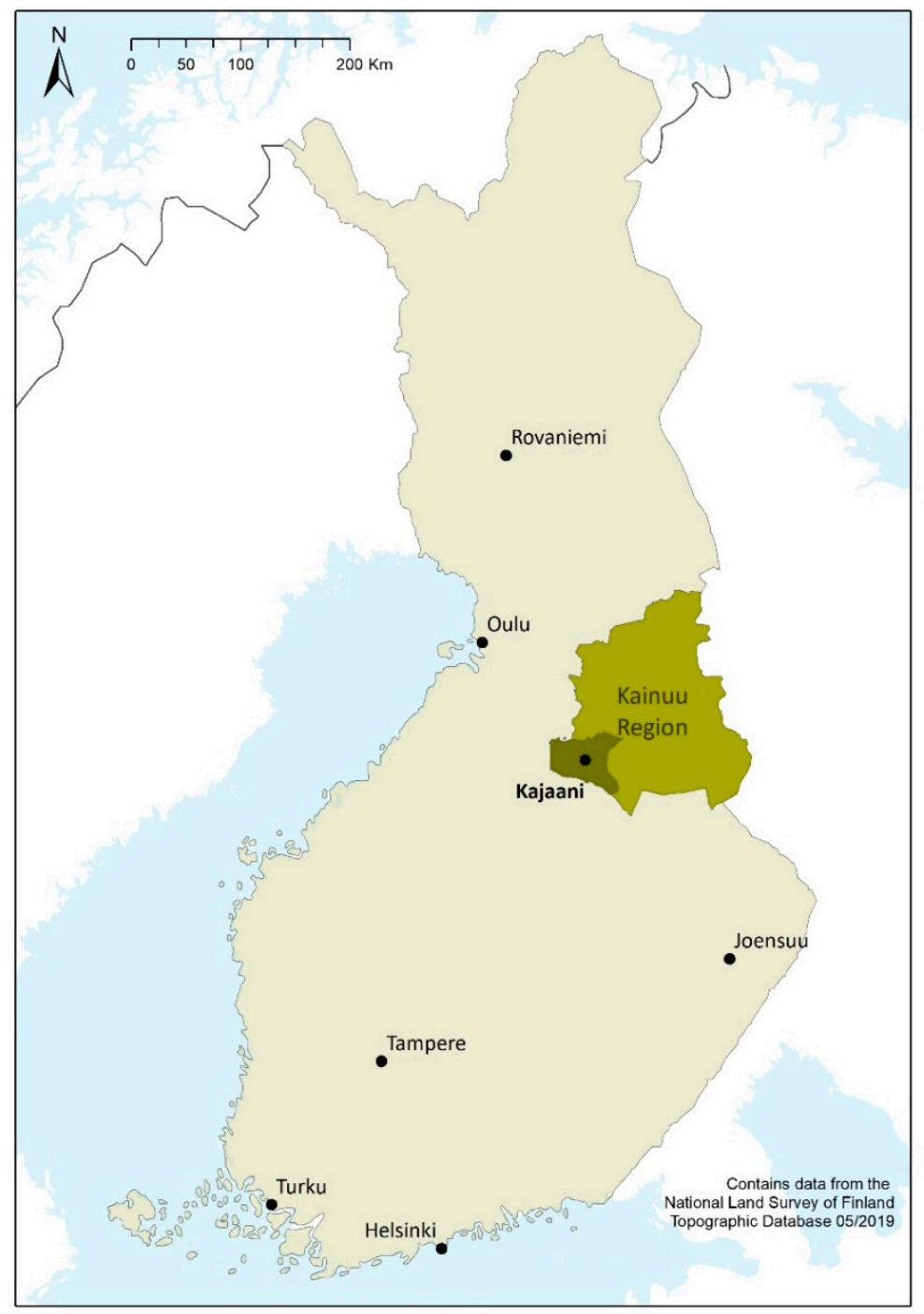

Figure 1. Finland and the location of Kajaani and the Kainuu region.

The state's decentralization policy has targeted Kajaani. As Kainuu's regional center, Kajaani serves as the location of many administrative offices. The town has a strong relationship with the entire Kainuu region, leading to the suggestion that Kajaani's image is filtered through that of the region, which is seen as backward and lacking in progress. Even the provincial anthem of Kainuu provides mostly hunger and misery. Although many efforts have been made to improve Kajaani's image, its identity and image are still viewed negatively. Nevertheless, the town is seeking to reconstruct its identity as a small town with good services and a dynamic economic life. Today, Kajaani has 37,304 inhabitants, and it is the thirtieth largest town in Finland. 
How do the ideas of Kajaani developers relate to previous concepts of success-how do they follow them, and how do they stretch them? To what extent can new innovative elements be found-how much follow-up and imitation is there of similar cases? [13]. This paper highlights how a declining town such as Kajaani is reacting to the state's changing role, and the development paths it is seeking to identify amidst altered circumstances. The dichotomy of this mechanism is that state dependency is a deep structural force of the narratives but simultaneously something original and unique is required.

\subsection{The Changing Role of Finland's Spatial Orientation}

As Toni Ahlqvist and Sami Moisio [14] (p. 21) highlight, state transformation takes different forms and evokes multiple responses in various geographical contexts. National industrial development in Finland at the local level can be conceptualized through three epochs of state space $[15,16]$. The first epoch, from 1920 to 1945, is defined as an areal state (13). During this period, cultural, government, and economic activity were concentrated in urban and core areas, especially in Helsinki. Regions outside the southern core areas were conceptualized mainly as fascinating hinterlands, national cultural phenomena, and the unknown periphery. The economy was generally based on agriculture and forestry. Moisio underlines that the state was relatively absent at the peripheries and, thus, social relationships were established at the local level.

At the local level, however, many small towns grew through industrialization. As new factories and houses were built, people moved into the towns from the countryside. Kajaani was then a lively town with educational opportunities. The Kajaani timber company played a crucial role in the town: one-third of Kajaani's taxpayers worked in the company in the 1920s, and the company paid almost one-fourth of Kajaani's municipal tax in the 1930s. However, the company was more than merely a taxpayer or employer in Kajaani: it paid for its workers' houses, schools, kindergartens, and healthcare. It also influenced local cultural life, arranging sporting events and housekeeping courses $[17,18]$. Thus, at the time, Kajaani was a typical paternalist welfare community, illustrating the ideal of modernization to its less developed neighboring areas.

Finnish public policy changed after the Second World War. It was the long-term president, Urho Kekkonen, who emphasized that the state should invest in the peripheries of the large country through the establishment of infrastructure and industry. The basic idea was to invest public funds in heavy industry and energy production in northern Finland, including the Kainuu region. Side inputs would be to significantly improve the road system and develop northern agriculture to meet the needs of increasing populations [19] (pp.103-118). From Kekkonen's theses to the end of the last century, the idea of 'northern reserves' was in the core of energy and forest policy - on which, alongside its defense political reasons, the goal of keeping the entire country inhabited was based [20] (pp. 50-51). The state gave financial support principally to large industrial plants which should be located in the central towns of peripheral regions.

Moisio [13] defines the second period, lasting until 1990, as the epoch of the decentralized welfare state. During this epoch, the state aimed to foster the nation's unity and root out the left-wing political radicalism that was seen as a threat to industrial communities. It was the political alliance formed by the Agrarian Party (later the Center Party) and the Social Democrats that enabled a massive social redistribution system across the state space [12,13]. With intensive cultural decentralization (new universities, libraries and arts institutions), the state attempted to create loyal citizens to make a small but largely populated nation more cohesive [21]. The idea was that every citizen should feel they belonged to Finland and had the same opportunities regardless of their living space. However, it should be kept in mind that decentralization was strictly in the hands of central government and there were no real decision-making powers in the regions. President and minor politicians were busy when they visited the inaugurations of industrial plants and state offices. Regional policy created a strong public sector, which explains a simultaneous increase in the workforce in the service and industrial sectors. Decentralization generated the middle class in every corner of the country. 
Kajaani was largely supported by the state during this period. For example, the University of Oulu established a pedagogical unit in Kajaani. The state invested heavily in industry and infrastructure in Kajaani and the Kainuu region. At the same time, new industries started to develop besides forestry. The timber company launched an electronics industry in the 1970s. The growth of the service sector and the establishment of university education led to a growing middle-class population, with the resulting spread of mostly state-organized cultural and leisure facilities. Overall, while the timber company was not the town's only employer, it also indirectly influenced local politics.

Moisio [13] defines the third epoch, from the beginning of the 1990s until the present, as the decentralized competition state. During this period the alliance between the Social Democrats and the Center Party withered. The collapse of the Soviet Union in the early 1990s, the most important trade partner of Finland, fundamentally changed the country's geopolitical position and drove it in a deep economic recession. In 1995, Finland entered the EU. Furthermore, unrestricted capital flows and neoliberal economic globalization undermined the economic sovereignty and capacity of an interventionist state [22]. Global economic competition caused pressures to cut taxation and public expenditures in view of competitiveness. Moisio [14] points out that the period was not only the end of a 'closed Finland' but the point at which the knowledge-based economy and the internationally oriented citizen became central. The ideal of knowledge-based economy was highlighted by the success of Nokia that was scattered around Finland as subcontracts.

The state's role was now to create market conditions in which regions and towns could operate and compete. The idea was that towns and regions should be competitive, open, and attractive to international investment. Regions and towns were expected to create their own strategies, based on their endogenous strengths. Consequently, regions were conceptualized as units that should have the opportunity to compete in international markets. In Kajaani, the metal, mining, and IT industries played significant roles. The gaming industry was a sector which raised special expectations. In the declining areas of Europe, the emphasis on the economic autonomy of peripheries and genuine endogenous strengths has attracted not only clearly original innovations but vigorous imitation of the best practices (similar pedestrian streets, bazaars and political populism throughout Europe [23]. Which alternatives are recognizable in the development narratives of Kajaani?

\section{Research Design}

Our research method is a narrative analysis because, at the narrative level, the motives for developing at various phases are connected in a flexible way. In practice, the aim was to identify themes and issues which were chained for narratives. The local dominant narrative is the most obvious storyline that can be found from official city documents, local histories and marketing texts. Such a basic storyline is something that people maintain in their everyday conversations and to which they commonly refer and/or react in various everyday life situations. In that sense, narrative is an arena in which meaning takes form, and in which individuals connect themselves to the public and social world. Therefore, though based on stories, narratives are also political instruments [24]. In centrally organized decentralization, divisions between the dominant base narrative and locally justified versions of it is crucial. The main question of the empirical study was, thus, how the interviewees and other documents managed to combine ideas of state-controlled decentralization with the neoliberal basis of knowledge-based economy locally?

The research material comprises two parts. The first contains fifteen interviews conducted in Kajaani between November 2017 and February 2018. Five interviewees represented local government (LG), four business (B), and six civil society (CS). The interviews were selected from the group of development-prone persons in order to make a representative sample to map official and informal interpretations of Kajaani's development realities. During the interview process, it was noticed that certain themes and issues were raised repeatedly. The saturation point was reached. New interviews did not bring new information for the research objectivities. Interviews lasted one to two hours and were recorded. Each interview was transcribed for later analysis. 
Additionally, this article is based on Kajaani's official strategy and editorials from Kainuun Sanomat, the Kainuu region's local newspaper. The aim was to analyze editorials covering Kajaani issues from the beginning of 2014 to the end of 2017-Kajaani and its future prospects as key words. The official strategy and editorials were selected to highlight how development ideas were considered publicly. The aim was to discuss what questions and problems are the most common in Kajaani. Overall, ninety-seven editorials were analyzed in detail. The analysis was conducted using the qualitative analysis program ATLAS.ti. After close reading of the research material, the editorials, interviews and official strategies were coded to sub-categories. Passages were selected so that they summarize information relevant to the research problem around similar themes (e.g., mining, IT industry, factory heritage). Each sub-category contained the same kinds of themes and issues. The close reading revealed that public texts (such as strategies and editorials) followed a certain line constituting the most sustainable narrative. The interviews, on the other hand, were twofold. On the one hand, they supported the selective narrative. On the other hand, they challenged and provided alternatives for it-all of which could be set under an umbrella of the knowledge-based economy.

\section{Results and Discussion}

This section introduces two partly nested but also mutually challenging narratives-the narratives of decentralization and knowledge-based economy—and how they have been adjusted to each other by locally relevant sub-narratives.

\subsection{The Narrative of Decentralization}

In the minds of Kajaani developers, the traditional narrative of decentralization had two distinct paths. Nowadays, decentralization (the state's strong presence in Kajaani and its positive impact on local development) was connected to mining, especially the Talvivaara mine (later Terrafame). The mine is in Sotkamo, approximately forty kilometers from Kajaani. Currently, Terrafame employs 600 people directly, and almost 1000 people indirectly. Half the mineworkers are from Kajaani. When Kajaani's paper mill closed in 2008, the Talvivaara Mining Company was viewed as a substitute for the factory and the savior of both the town and the entire Kainuu region. Mining's role in the narrative of decentralization highlighted two essential features. The first was connected to the big actor mentality. Only a big company would make Kajaani more the kind of city the neoliberal world order requires. Talvivaara/Terrafame was just such a leading actor.

Talvivaara saved the region after the closure of the UPM paper mill. Without Talvivaara, Kainuu would have been trapped in a ravine from which the escape would have been troublesome and slow [25].

Without a clear industrial strategy and big objectives, it is impossible to improve the economy. The pyramid stands better when it has solid foundations. Kainuu's big industrial projects have been UPM and Talvivaara [26].

Secondly, mining was conceptualized as a national issue, and the Finnish state should therefore be concerned about the mine's future. Many official actors observed that if the state wished to sustain regional equality, remote towns and areas should have big companies to bring well-being to the whole region. The state was needed especially for initial investments for improving infrastructure and for reducing hindering bureaucracy. This mentality reflected the period when state-owned companies played a significant role in the development of peripheral areas.

The second theme of the decentralization narrative was the new forms of industry that were part of the knowledge-based economy. The research material highlighted three such activities. The first was the bioethanol plant in Kajaani at the former UPM paper mill, which reached full capacity in early 2017. The plant produces advanced renewable ethanol from sawdust, a process residue from sawmills. The plant has a considerable direct and indirect impact on the Kainuu region and has been easy to couple with the regional bio-economy strategies of Finnish governments. Although the bioethanol plant utilizes a high degree of processing and is involved in innovative research, it is 
closely connected with Kajaani's industrial history. Its location and the natural resources used meant that the bioethanol factory was interpreted as a continuation of the former paper mill and its legacy. However, it was no longer seen as primary industry: the expertise the plant required makes it part of the knowledge-based economy.

The second project involved Transtech, a major domestic manufacturer of railway and tram rolling stock. It specializes in manufacturing railway vehicles and trams for use in extreme climates. The company's office is in Oulu, but its main manufacturing base is in Otanmäki, Kajaani. Transtech employs more than 600 people in Kainuu, making it a significant employer in the region. Transtech was one factory that firstly suffered from the EU's strict competition rules but has since gained many public procurements.

The third activity involved the rise of the gaming industry. The research material indicated that promising developments were emerging in computer gaming in Kajaani. Although the gaming industry represents a new and innovative field, it is linked with the town's industrial past. The current measurement technology on which the gaming industry is partly based was developed from the electronics business Kajaani PLC (later the UPM paper mill) established forty years ago. All these suggest that the ideal of decentralization and its multiplier effects are still alive among the advocates of Kajaani.

\subsection{The Narrative of the Knowledge-Based Economy}

The narrative of decentralization included a strong belief in centrally organized decentralization: However, from the local research material, it was possible to identify abnormal or even opposing discourses most of them under the umbrella concept of the knowledge-based economy. This concept refers to the advanced economies that 'are directly based on the production, distribution and use of knowledge and information' [27] (p. 7). However, as Luukkonen and Moisio [4] (pp. 1456-1457) mention, the knowledge-based economy refers to 'a combination of discourses and institutional as well as administrative mechanisms and structures of knowledge that render the social reality of the EU thinkable in a particular way.' It is therefore more than a European economic system or occupational structure. In this context, besides knowledge and economy, the knowledge-based economy was connected with creativity, expertise, and, on the larger scale, the attractiveness of the whole town (5).

The narrative of the knowledge-based economy provided ground for three interrelated local narratives. It was a basic story line, a kind of universal obligation that all economic strategies should follow. The first was the narrative of the small town. It was derived from Kajaani's identity and allegedly individual senses of place. Here, the question not only concerned Kajaani but the Kainuu region as a whole. The interviewees spoke of a unique and original Kainuu mentality. Many felt that regional identity in Kainuu was especially strong compared to other regions. Representatives of Kajaani thought that Kainuu identity is a strong endogenous character of Kajaani simultaneously relieving the feasibility of regional identity.

The small-town narrative contained three themes. The first was pride in the home region. This was manifested by a silent emphasis on the locality's strengths which also created dividing line between Kajaani and the growth centers of Finland. Thus, interviewees sought to demonstrate the uniqueness and superiority of Kajaani and the Kainuu region, while larger cities were presented as places that were 'not good for human beings.' They stressed that Kajaani had 'something' which could not be found anywhere else. This 'something' was often nature and its proximity.

A[nswer](B1): As the population shrinks, so does potential purchasing power. But it also burdens the services taxes provide. So, our dependency ratio is increasing. Will we be supported by state aid?... In a way, I believe that one day people in metropolises will tire of living such a narrow existence and will want the effortless everyday life you can find here, if only there were some work available. ... When I listen to people of my own age [about 40] who live there [the growing centers], who may have a few children, house and with two people working, the pay isn't enough. ... When you think of the Kainuu region, you think of roaming in the snowy forests where a lynx may jump out from behind a 
tree. And this is how the media usually portrays us. Or that the electricity gets cut off for five days, but people still live here. Yes, our public image is too connected to wild nature and the low level of services [25].

Interviewees also referred to the ease of everyday life. Moving to the town was regarded as fear of making an effort. The people of Kajaani would be open-minded and approachable, making it easy for outsiders to settle in the town. Pride in the home region included a certain shyness and modesty. Some interviewees felt that uncertainty underlays the silent pride.

Q: Are people here proud of being from Kajaani? Quite a few people have mentioned their pride in the Kainuu region.

A(LG1): Perhaps it's unique to Kainuu, perhaps a little of it's to do with Kajaani. There's a little silent pride here, not loud boasting. ... This is quite a tolerant town. It's easy to come here [26].

Is this shyness something caused by the cultural uncertainty for the disparity between Kajaani and the larger cities is a question worthwhile to ask [28]. To be uncertain of one's identity in the peripheries could reflect the fact that ideological regionalization is not that powerful an aim in the center anymore. People may think that heroic peripheries have turned into old-fashioned and anti-modern environments in the minds of urban people.

The second theme in the small-town narrative was an emphasis on smallness. According to the interviewees, people in Kajaani pulled together more than they had previously and at the same time they rejoiced in the successes of others. Smallness was seen as an advantage, because all the actors were close, and there were no barriers. Access to decision makers was therefore easy for those who wanted it, making it possible to influence local policy through their own activity. Smallness was thus interpreted as affording equality and placing everyone 'on the same boat'.

A(B1): In my opinion, when all the actors are small and work together, something bigger happens. And there'll be times when we can arrange an event that attracts a lot of people. In those moments we have something unique... So there's something unique about Kainuu. We're slowly getting used to the idea that a friend's success might be good for me too [25].

The second local narrative was the narrative of closure, concerning the closures of the paper mill and the teacher training school. When the plant closed in 2008, its former facilities were quickly reused. Many of the unemployed found new work, though some failed to do so. Overall, interviewees emphasized that the transformation had gone well. They saw as a key reason for this that the town did not get stuck in a rut but was able to look to the future. Interviewees pointed out that the aforementioned small-town identity and spontaneity were significant factors in the town's survival.

Although the decision to close the plant was dramatic, it did not come as a surprise. Now, ten years later, the interviewees saw the closure as a positive event for the whole town. Interviewees were even proud that there had been no significant opposition to the closure, as was the case in many other places where factories had been closed. This rather exceptional attitude must have something to do with UPM's considered style to arrange the closure and its touching up that partially made the developers to think that the closure was right thing to do. They highlighted three issues in support of this. The first was that the mill had served as a restrainer and deterrent. When it was operating, the town did not actively develop new economic activity. The paper mill created the illusion that one big actor could create prosperity endlessly. New businesses did not emerge in the town because of the strong faith in the factory. Because the dominant narrative stressed the plant's omnipotence, other activities were seen as 'dabbling'.

A(B2): When the news [about the closure of the paper mill] came, I was in Helsinki at a seminar ... And someone said to me that this was probably sad news. But I replied that it was a great thing, because we had been under this big actor for so long. It had prevented new businesses emerging ... [Regionally important actors] thought [before the closure] that if small businesses were started, it wasn't important... So the emphasis was always on something big. Here, you could easily be complacent and think the paper mill would always be here and always bring a stream of money and income into the region. And when it closed, we had to think about things in a new way. If you think of the last ten 
years, the attitude toward entrepreneurship has radically changed. When there were attempts to bring entrepreneurial studies into educational institutions before, the opposition was just incredible. Now, when you look at what's happened, the University of Applied Sciences and the Vocational School have been tasked to promote entrepreneurship... It was in 2007 and 2008 that it became necessary to think of new ways to act. It forced people to cooperate more closely in this region [25].

Secondly, the mill was seen as a golden cage. It was practically its own separate unit within the town. Although the plant employed many locals, its activities remained remote. Its physical appearance and architecture, with its guards, surveillance equipment, and gates created an image of a closed space operating apart from the town. Although several companies have replaced the paper mill and work in the factory building, the area is still a starkly guarded space. Many new entrants see the site as both restrictive and oppressive.

A(LG1): I moved to Kajaani at the beginning of 2000 and at that time the paper mill looked after everything. It was kind of like a golden cage, which did not appear in the town directly [26].

A(B3): I've been asked a couple of times why we don't move to Renfors Ranta Business Park [the location of the former paper mill] because we're so cramped here. Well, my answer is that it's far away from everything and I don't like the message it sends visually. When I go there, there are the gates, and I have lived my life behind gates. I don't understand it. There aren't any factory machines any longer ... Why do they control it? Why haven't they cleared them away? It would bring the park closer to the town center... If you want to move forward, you have to destroy the frameworks because they tell you how much you can grow within them [25].

The factory was not presented as a golden cage only through its physical and architectural framework but also by the people working there. In addition to relatively high pay, factory workers received many benefits others lacked. The factory was not only a workplace, it cared for its employees' families, from their leisure activities to their health care. Taken together, these two factors created an image of the factory as a closed golden cage with no tangible connection with other townspeople (cf. 2).

Thirdly, the plant was defined as an enabler of new things. Although the operations of the paper mill had ceased, the new companies situated in the factory buildings were able to avail of its physical, immaterial, and infrastructural benefits. The cheap heating, water, and steam the paper mill had produced and utilized had a major impact on the current companies' decision to locate themselves in its buildings. Although UPM had ceased its operations in Kajaani, the factory's legacy had a major impact on the town's current corporate structure. Equally, the gaming companies were involved in the electronics industry, which had been developed in the 1970s as part of the paper mill's operations.

Altogether, according to Kajaani developers, the closure of the factory cleared the path for new economic opportunities such as the gaming and film industries. Because of the transformation process Kajaani lost some of its industrial character. However, the paper mill's legacy is still visible in the town. The point that the company itself helped to develop new activities also helped to forget the closure. In many other cities in Finland (Kemijärvi, Voikkaa, Outokumpu), the longing for the mill's golden age is still high. It may be that the disappointment caused by the closure of the mill has not been addressed publicly in Kajaani, as it would be impossible to restore it. Instead, it makes sense to secure the support of a large company for any compensations.

Some interviewees criticized that the town's policy still favored big actors. They suggested that Kajaani had an old-fashioned notion of the 'right kind' of work. Only industrial work was seen as 'real' work, which was why new approaches to work and well-being were lacking in the Kainuu region as a whole. This was also manifested in the official attitude to forests and nature. The critics maintained that Kainuu was only conceptualized as a provider of resources for the use of forestry and mining industries. The interviewees presented the former paper mill in a negative light. Despite its significant role in Kajaani for a long time, younger generations especially viewed the plant as distant and strange.

A(CS1): There's a contradiction between work and nature, and work and well-being, which I think is very common in Kainuu. Changes and transformations happen here slowly. Another kind of job is not a job if it's not done in an old-fashioned industrial workplace. And then, when it has difficulties, 
it hangs on one way or another. In Kainuu much work needs to be done for a new perspective on work and well-being to emerge [29].

The narrative of closure included the closing of Kajaani's teacher training unit. Compared to the paper mill, it was expressed as more dramatic. The question not only concerned the closure of the unit itself, it had a significant impact on the atmosphere of the town as a whole. Alongside the death of education and new ideas-as one interviewee dramatically expressed it—one outcome was the disappearance of university students, which affected the town's image and mindscape. Many events and stunts the teacher education students organized came to an end.

Q: Which was the bigger thing for the town: the closure of the teacher training unit or the paper mill?

A(CS2): Well, if you think about the shutdown of the paper mill, the indirect effect was maybe 1000 or 1500 jobs. If you think about the teacher training unit, that meant 200 jobs, but then there was the exit of the students. They organized all kinds of event, so the town center became a little anemic after they had gone.... We lost skilled people who'd been here for decades. That was traumatic.

Q: Does it cause bitterness?

A(CS2): It's such a wound. That when you try to talk with people, you end up with a shutdown - they played a bad trick on us [29].

The closure of the paper mill was the decision of a private company; the demise of the teacher training unit was part of the state policy that, according to the dominant narrative, should have helped Kajaani in tight situations. However, also private companies had formerly benefitted from the public investments and state industrial strategies. The new idea was that in the neoliberal era, the state would not hold private companies socially or morally responsible.

The third local narrative that stood out in the material was the narrative of traction-the question of how to preserve the town's attractiveness to retain new residents and to keep skilled people in Kajaani. The interviewees saw the decline and aging of the population as Kajaani's main problem. They observed that Kajaani did not have enough skilled workers for the needs of new, modern industries. This was a big challenge for many companies, also affecting their activity and future plans. The interviewees said that if skilled workers came only seasonally to Kajaani, such as in the case of construction, they would not lay their roots in the town. With no proper bond to Kajaani, the city would always stay distant to them. Furthermore, people had no interest in participating in the town's daily life and development.

A(LG1): Engagement with the region is a pretty interesting question. When I came to the polytechnic in 2004, 70\% [of the students] were from Kainuu, and 30\% came outside the region. Now, it's the opposite. It raises various questions. First, they lack the social networks many students had before. So, how do we create our education so that they sense belonging to the region?... We have to involve local companies in the education. The students have to get to know those companies... So, after graduation between fifty and sixty percent continue to work here. That is, we're importing labor [26].

The interviewees mentioned that it was not merely a job which would be the essential feature to traction, as workplace or pay-check were no longer the only features that encourage people to stay. Kajaani should offer something more. That 'something' was apart from the surrounding nature urban environment and social relationships. The urban environment must be attractive, and it should offer people leisure opportunities. Moreover, if new residents lacked networks and therefore always felt themselves as outsiders, they would eventually leave the town. The availability of a skilled workforce and its commitment to Kajaani were not problems merely for a particular workplace or company, but in the long term it would affect the whole town.

A(B2): Our greatest threat is the losing of talent. If you think that our management consists of single young males, then this is a serious threat. For example, shortly before you came there was a discussion here about the fact that not everyone here is happy. And that's when we have to let the cat out of the bag. 
Q: Do you face a risk that some of the staff will leave, and you won't be able to get anyone to substitute?

A(B2): Certainly. Even though we're trying to be proactive, we are still reactive in recruiting processes. Which is why the existing team is pressurized by constant overwork. No one can handle that... for the majority of people it is their first job.

Q: So, could you hire more people here? Or is it impossible?

A(B2): Well, we don't get the people we need who offer us the time we need.

Q: So, is their area of expertise so small that you can't find anyone?

A(B2): Expertise is one thing; it's quite another to move to Kajaani. And then thirdly-the priority-are they suitable for our company?

Q: How do you present Kajaani? After all, people need to feel comfortable in this environment.

A(B2): In the recruitment process, we first look at the CV. Then we'll talk and ask, 'How about Finland? Why Finland?' Or, 'Why Kajaani?' And when the video interview has come to an end, we see if they have the potential to work with us ... Nothing else really matters. Of course, you work in English. Then we bring him or her here to Kajaani for about three days. I don't tell them so much, but I show them.

Q: What do you show them?

A(B2): What's beautiful here.

Q: So, where exactly do you take people?

A(B2): Well, I take them to neighborhoods where there are old wooden houses... I show them schools and kindergartens. And then I show them the environment. So, to be honest, all the selling points are non-industrial. It depends on where they come from. Some may be interested in the green color of the forests. That green color is quite different from what they have in Argentina.

Q: Is that an aesthetic thing?

A(B2): Yeah, what I'm trying to say is that something can also be beautiful [25].

The narrative of traction was also connected to young people leaving Kajaani. This was a product of the lack of educational choices. When young people go elsewhere to study after high school, only a few will return to their hometown. Although the media has occasionally focused on returnees, the interviewees pointed out that remigration has been exaggerated. At the same time, they stressed the importance of Kajaani's University of Applied Sciences (polytechnic). Without it, many companies would be in trouble. In the gaming industry especially, the University of Applied Sciences was seen as a key factor in maintaining its success.

Overall, the narrative of traction merged with the question of Kajaani's peripheral location. In this context, remoteness was not defined simply as distance from the large cities, but in many respects, it was the mentality through which the town's image was determined. The peripheral mentality has a long history in Kajaani and especially in the Kainuu region. It is not only physical or mental remoteness that defines it. Strong confidence in self-making plays a role too. The essential undertone is, thus, that no external actor will help Kajaani and the surrounding region even if the return of Kekkonen is sometimes secretly hoped.

\section{Conclusions}

Research on post-industrial communities concentrates on the economic or social sides of their development. Changing symbolic meaning, and not only for the community itself but in wider nation-state strategies, has been addressed rarely. However, as shown in this analysis, it is clear that the community's tradition and collective identity are important frameworks for the future visions of local developers.

The concept of decentralization has characterized Kajaani and its recent history; it also created the still dominating base structure for narratives describing paths from the past to a desirable future. Here, the narrative of decentralization refers to the state's strong presence in remote towns and peripheral areas, which resulted in the expectations that the state would take care of Kajaani and 
its surrounding region, as it had since the 1960s by establishing state offices, infrastructure and new education opportunities. The advocates of Kajaani still emphasize the state's role in backing up local strategies. The narrative often implied the significance of big actors: one big company could offer enough jobs to the region. In the 1990s, the idea of decentralization began to receive more political attention. Foreign private investment has become essential for generating growth as the state has slowly withdrawn support from remote areas. In Kajaani, the fall came from a high. After all, it was for long a model of the industrialization and decentralization policies of Finland. The town now needs to offer 'something' other cities and towns cannot in competition for talent.

Local narratives recognized here were all bound by the narrative of decentralization. However, the common denominator of the three of them was the promise of the knowledge-based economy for places in decline. When the dominant narrative was originally connected to the 'Fordist' features of the modern world, such as rigid factory work, regularity, strong control and clear separation of work and leisure time, the narrative of the knowledge-based economy flirted with many characteristics of the post-modern world: emphasis on creativity, information and knowledge, entrepreneurship, weak state, pro-environmental orientation, the integration of work and leisure, and an emphasis on higher education.

The dominant and local narratives therefore contained discursive contradictions and conflicts. First, whereas the dominant narrative underlined the role of big actors as the guarantor of the town's economic vitality and prosperity, the local narratives also emphasized the role of small actors. For some massive and rigid actors represented the past, while small- and medium-sized companies represented the present and future. Although they accepted the impact of the big companies on local employment, the alternate local narratives saw that if economic life was based only on big actors, it easily led to partiality. Second, the local narratives included desire to develop the town center. This view conflicted with the dominant narrative that was symbolically attached to the ideas of peripheries as 'modern wilderness'. From this perspective, the town space and its places were cast in a completely new role. They were not simply the background or the arena of events, but an essential factor in the town's vitality. In this context, there were some generational differences. While young people spoke about the contribution of urban culture, older people saw this as 'just nice dabbling.' Third, while the dominant narrative separated well-being and work, some local discourses connected them. Consequently, the essential issue was how work could be connected with leisure time and the everyday life. This perspective was socially pervasive, as it combined the production of the town space and the organization of people's private life.

Taken together, these three clashes in narratives point to a widespread social transformation that has occurred in Kajaani X. However, it seems fair to say that contradictions take place primarily at the discursive level, following different mentalities of rule, whereas the material goal is basically the same. Although transparency is regarded highly, openness easily becomes a mask which conceals social evils. It has meant that the marginality that was a basis for overall political strategy in the past has become something that should be hidden. Even in the case of closures, the public revenge of the locals mentioned in Rodriguez-Pose's article (9) is not visible in the thoughts of the interviewed developers. Perhaps appealing would only illustrate belonging to the margins. Instead, the knowledge-based-and illusion-based economy (game industry, cultural industry)—would make communities resemble the neoliberal ideal a bit more.

New societal discourse favors independent initiatives and endogenous strengths, whereas, in practice, knowledge- and illusion-based economies encourage imitation from those practices that have worked elsewhere. In Kajaani's case, it has meant imitation that joins together the illusion of the pleasant old days and the imagined ideal of a neoliberal city. Imitation more than being conscious is a passive phenomenon. The problem would be, as Krastev and Holmes put it, that pursuing economic and political reform by imitating a foreign model easily turns out to have moral and psychological downsides: feelings of inadequacy, inferiority, dependency, and lost identity. It also entails the assumption that such areas accept the outsiders right to evaluate their success or failure at living 
up to the standards of global capitalism (12) (p. 125). In this sense, imitation may result in feeling like a loss of sovereignty. On the other hand, the line between genuine innovation and imitation is blurred. Creative imitation often contains genuinely new elements. If truly local difference makers could be recognized in the research material, they deal with the benefits of the operational environment. They are 'special strengths' - different from those of metropolises—such as plenty of space, silence, and unspoiled nature. Further, this is not only an internal impression. Even if the state has partially withdrawn its support, the idea of 'northern reserves' is little by little adopted by the EU as well, because the natural resources within the economic area are scarce and dependence on questionable trade partners is significant [30].

Author Contributions: Conceptualization and theoretical frameworks, S.H. and J.S.; methodology, J.S.; validation, S.H. resources, S.H.; writing-original draft preparation, S.H. \& J.S.; writing-review and editing, S.H.; visualization, J.S.; supervision, S.H.; project administration, S.H.; funding acquisition, S.H.

Funding: This paper was funded by the JPI Urban Europe project BRIGHT FUTURE co-financed by European Union's H2020 funds and national funds, in this case Academy of Finland, grant number 312011.

Conflicts of Interest: The authors declare no conflict of interest. The funders had no role in the design of the study; in the collection, analyses, or interpretation of data; in the writing of the manuscript, or in the decision to publish the results.

\section{References and Notes}

1. Lazzeroni, M. Industrial Decline and Resilience in Small Towns: Evidence From Three European Case Studies. Tijdschr. Voor Econ. Soc. Geogr. 2019. [CrossRef]

2. Häyrynen, S. Cultural Continuity; The Former mining community of Outokumpu as an intermediary of symbolic capital. In Locality, Memory, Reconstruction: The Cultural Challenges and Possibilities of Former Single-Industry Communities; Häyrynen, S., Turunen, R., Nyman, J., Eds.; Cambridge Scholar Publishing: Cambridge, UK, 2012.

3. Marshall, N.A.; Park, S.E.; Adger, W.N.; Brown, K.; Howden, S.M. Transformational capacity and the influence of place and identity. Environ. Res. Lett. 2012, 7, 034022. [CrossRef]

4. Scott, A. Globalisation and the Rise of City-regions. Eur. Plan. Stud. 2001, 9, 813-826. [CrossRef]

5. Florida, R. Who's Your City; Basic Books: New York, NY, USA, 2008.

6. Jonas, A.E.G. City-regionalism: Questions of distribution and politics. Prog. Hum. Geogr. 2012, 36, 822-829. [CrossRef]

7. Luukkonen, J.; Moisio, S. On the socio-technical practices of the European Union territory. Environ. Plan. A 2016, 48, 1452-1472. [CrossRef]

8. Glaeser, E.L. Triumph of the City: How Our Greatest Invention Makes Us Richer, Smarter, Greener, Healthier and Happier; Penguin: New York, NY, USA, 2011.

9. Rodriguez-Pose, A. The revenge of the places that don't matter (and what to do about it). Camb. J. Reg. Econ. Soc. 2018, 11, 189-209. [CrossRef]

10. Small, R.; Syssner, J. Diversity of new uses in post-industrial landscapes: Diverging ideals and outcomes in the post-industrial landscapes of Lowell, Massachusetts and Norrköping, Sweden. J. Urban Des. 2016, 21, 764-784. [CrossRef]

11. Ameel, L. Narrative Mapping and Polyphony in Urban Planning. Yhdyskuntasuunnittelu Finn. J. Urban Stud. 2016, 54, 20-40.

12. Moisio, S.; Leppänen, L. Towards a Nordic competition state? Politico-economic transformation of statehood in Finland, 1965-2005. Fennia 2007, 185, 63-87.

13. Krastev, I.; Holmes, S. Explaining Eastern Europe: Imitation and Its Discontents. J. Democr. 2018, 29, 117-128. [CrossRef]

14. Ahlqvist, T.; Moisio, S. Neoliberalisation in a Nordic State: From Cartel Polity towards a Corporate Polity in Finland. New Political Econ. 2014, 19, 21-55. [CrossRef]

15. Moisio, S.; Vasanen, A. Alueellistuminen valtiomuutoksen tutkimuskohteena [Regionalization as an object of the study of state transformation]. Tieteessä tapahtuu 2008, 3-4, 20-31.

16. Moisio, S. Towards transnational spatial polices in Finland. Nord. Geogr. Publ. 2015, 44, 87-93. 
17. Virtanen, S. Kajaani Oy 1907-1982: 1, Kainuuseen Sijoitettu: Kuvaus Kajaani Oy:n Vaiheista Vuoteen 1945 [Kajaani PLC 1907-1982: 1, Located to Kainuu: A Description of the Phases of Kajaani PLC Until 1945]; Kajaani Oy: Kajaani, Finland, 1982.

18. Virtanen, S. Kajaani Oy 1907-1982: 2, Puusta Elävä: KAJAANI Oy:n Vaiheita Vuodesta 1946. [Kajaani PLC 1907-1982: 2, Wood As A Source of Livelihood: Phases of KAJAANI PLC Since 1946]; Kajaani Oy: Kajaani, Finland, 1985.

19. Kekkonen, U. Onko Maallamme Malttia Vaurastua? [Does Our Country Have A Temper to Prosperity?]; Otava: Helsinki, Finland, 1952.

20. Kuisma, M. Euroopan metsäaitta ja nopea sopeutuja. Suomalaisen taloushistorian pitkä linja. [The long line of Finnish economic history]. Suomi outo pohjoinen maa. Näkökulmia Euroopan ä̈ren historiaan ja kulttuuriin; Lehtinen, T., Ed.; PS-kustantamo; WSOY: Porvoo, Finland, 1999; pp. 50-85.

21. Häyrynen, S. Renegotiating Cultural Welfare: The Adoption of Neoliberal Trends in Finnish Cultural Policy and How It Fits the Nordic Model of a Welfare State. In Art and the Challenge of Markets; Volume 1 of Two Volumed Compilation; Alexander, V., Hägg, S., Häyrynen, S., Sevänen, E., Eds.; Palgrave \& McMillan: Cham, Switzerland, 2018; pp. 155-181.

22. Schmidt, V.; Thatcher, M. Theorizing Ideational Continuity: The Resilience of neo-liberal ideas in Europe. In Resilient Liberalism in Europe's Political Economy; Schmidt, V., Thatcher, M., Eds.; Cambridge University Press: Cambridge, UK, 2013; pp. 1-50.

23. Whelan, Y.; Moore, N. Heritage, Memory and the Politics of Identity: New Perspectives on the Cultural Landscapes; Ashgate: Aldershot, UK, 2007.

24. Polletta, F. It Was Like a Fever: Storytelling and Protest and Politics; University of Chicago Press: Chicago, IL, USA, 2006.

25. Interview. Business (B), 2018.

26. Interview, Local Government (LG), 2018.

27. OECD, Organization for Economic Cooperation and Development. The Knowledge-Based Economy; OECD: Paris, France, 1996.

28. Green, R. Meaning and Form in Community Perception of Town Character. J. Environ. Psychol. 1999, 19, 311-329. [CrossRef]

29. Interview. Civil Society (CS), 2018.

30. Growth from the North. How Can Norway, Sweden and Finland Achieve Sustainable Growth in the Scandinavian Arctic? Report of An Independent Expert Group; Prime Minister's Office Publications: Helsinki, Finland, 2015. 